\title{
Pembangkit Listrik Hybrid Solar Cell dan Turbin Angin di Pantai Tamban Kabupaten Malang
}

\author{
${ }^{1}$ Aris Ansori * ${ }^{2}$ I Wayan Susila, ${ }^{3}$ Indra Herlamba Siregar, ${ }^{4}$ Subuh Isnur Haryuda \\ 1,2,3 Teknik Mesin, Universitas Negeri Suarabaya, Indonesia. \\ ${ }^{4}$ Teknik Elektro, Universitas Negeri Suarabaya, Indonesia. \\ 1arisansori@unesa.ac.id, ${ }^{2}$ wayansusila@unesa.ac.id, ${ }^{3}$ indrasiregar@unesa.ac.id, ${ }^{4}$ subuhisnur@unesa.ac.id
}

\begin{abstract}
Abstrak
Permasalahan masyarakat di pesisir pantai di kabupaten malang adalah energi listrik. Suplai energi listrik PLN yang kurang menjadi masalah untuk kebutuhan listrik sehari-hari masyarakat pesisir pantai untuk penerangan. Potensi intensitas matahari yang rata-rata perhari $600-1000 \mathrm{~W} / \mathrm{m}^{2}$, potensi energi angin dengan kecepatan rata-rata $2-6 \mathrm{~m} / \mathrm{s}$ dapat dimanfaatkan untuk sumber energi pembangkit listrik energi terbarukan. Penelitian ini bertujuan menganalisis pemanfaatan energi matahari dan energi angin di pesisir pantai Tamban Kabupaten Malang untuk dikonversi energi listrik. Penelitian ini menggunakan turbin angin sumbu vertikal darrieus-H NACA 0018 modifikasi untuk menggerakkan generator AC 300 watt 3 fase dan modul solar cell 1000 WP monokristal. Hasil dari penelitian model pembangkit listrik solar cell-turbin angin menghasilkan daya listrik solar cell $1,98 \mathrm{KW}$ per hari dan pembangkit listrik turbin angin rata-rata menghasilkan 33,2-33,5 watt. Performa tertinggi terdapat pada beban 100 Watt dengan efisiensi sebesar $64,72 \%$. Sedangkan efisiensi terendah terdapat pada beban 25 Watt dengan efisiensi sebesar $63,68 \%$, sehingga model pembangkit listrik hybrid solar cell-turbin angin memiliki efektifitas dan efisien yang baik untuk diterapkan di daerah pesisir pantai.
\end{abstract}

Kata kunci: Potensi, energi matahari, energi angin, pesisir pantai

\section{PENDAHULUAN}

Pemanfaatan energi baru dan terbarukan sebagai sumber energi dalam Kebijakan Energi Nasional (KEN) sebesar 23 persen dari total energi bauran (energi mix) pada tahun 2025 dan 31 persen pada tahun 2050. Data Kementerian Energi dan Sumber Daya Mineral (ESDM) menyebutkan bahwa saat ini persentase energi baru dan terbarukan dari total produksi energi primer masih berkisar pada level dibawah 5 persen. Pemanfaatan energi matahari dan angin yang merupakan energi dengan jumlah berlimpah, ramah lingkungan [1]. Karenanya, energi matahari dan angin sebagai sumber energi alternatif semakin banyak digunakan dalam berbagai aplikasi kebutuhan energi sehari-hari.

Pemanfaatan energi terbarukan energi matahari dan energi angin dipesisir pantai potensial untuk sumber pembangkit listrik di pesisir pantai. Energi sinar matahari yang diterima oleh permukaan bumi sebesar $69 \%$ dari total energi pancaran matahari. Suplai energi solar cell dari sinar matahari yang diterima oleh permukaan bumi mencapai $3 \mathrm{x}$ 10 joule pertahun, energi ini setara dengan 2 x 1017 Watt. Sedangkan potensi kecepatan angin sebesar $2-6 \mathrm{~m} / \mathrm{det}$ (siang hari) dan $5-7 \mathrm{~m} / \mathrm{det}$ (sore-malam hari) dapat

\section{Abstract}

The problem of people on the coast in Malang is electricity. PLN's electrical energy supply is less a problem for the daily electricity needs of coastal communities for lighting. The intensity of solar intensity is $600-1000 \mathrm{~W} / \mathrm{m}^{2}$, wind energy potential with an average speed of $2-6 \mathrm{~m} / \mathrm{s}$ can be used for renewable energy power plants. This study aims to analyze the utilization of solar energy and wind energy on the coast of Tamban Malang Regency to convert electricity. This study used a modified vertical axis wind turbine darrieus-H NACA 0018 to drive a 3 phase AC 300 watt generator and 1000 monocrystal WP solar cell module. The results of research on solar cell-wind turbine power generation plants produce $1.98 \mathrm{KW}$ of solar cell electricity per day and wind turbine power plants generate an average of 33.2-33.5 watts. The highest performance is in the 100 Watt load with an efficiency of $64.72 \%$. While the lowest efficiency is in the 25 Watt load with an efficiency of $63.68 \%$, so the model of hybrid solar cell-wind turbine power plant has good effectiveness and efficiency to be applied in coastal areas.

Keywords: Potential, solar energy, wind energy, electricity, coastline

dimanfaatkan untuk menggerakkan turbin angin. Penggunaan sel fotovoltaik (PV) untuk mengubah sinar matahari menjadi arus listrik menggunakan efek fotovoltaik [2]. Sel fotovoltaik (PV), adalah perangkat yang dibuat dari bahan yang menunjukkan efek fotovoltaik yang terdiri sejumlah sel membentuk modul fotovoltaik yang dapat menghasilkan listrik pada tegangan arus searah, sedangkan arus yang dihasilkan secara langsung dipengaruhi jumlah cahaya yang mengenai modul [3].

Energi yang dipancarkan oleh sebuah cahaya dengan panjang gelombang $\lambda$ dan frekuensi photon $V$ dirumuskan dengan persamaan:

$\mathrm{E}=\mathrm{h} . \mathrm{c} / \lambda(1)$

Dengan :h adalah konstanta Plancks (6.62 x 10-34 J.s) $108 \mathrm{~m} / \mathrm{s}$ ).

c adalah kecepatan cahaya dalam vakum $(3.00 \mathrm{x}$

Persamaan di atas juga menunjukkan bahwa photon dapat dilihat sebagai sebuah partikel energi atau sebagai gelombang dengan panjang gelombang dan frekuensi tertentu.

\section{A. Parameter Kinerja Sel Solar cell}


Sel solar cell komersial menghasilkan tegangan dc sebesar 0,5 sampai 1 volt, dan arus short-circuit dalam skala milliampere per $\mathrm{cm}^{2}$. Besar tegangan dan arus ini tidak cukup untuk berbagai aplikasi, sehingga umumnya sejumlah sel solar cell disusun secara seri membentuk modul solar cell. Satu modul solar cell biasanya terdiri dari 28-36 sel solar cell.
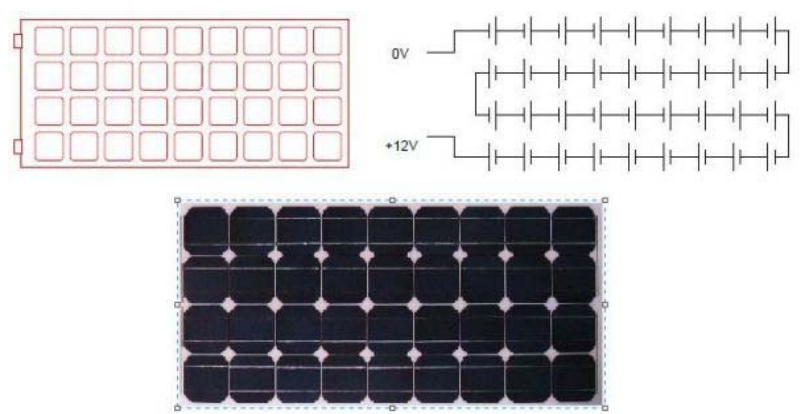

Gambar 1 Modul solar cell terdiri dari 28-36 sel

Performa sel solar cell dilihat dari daya ouput listrik yang dihasilkan. Daya listrik yang dihasilkan sel solar cell ketika mendapat cahaya diperoleh dari kemampuan perangkat sel solar cell tersebut untuk memproduksi tegangan ketika diberi beban dan arus melalui beban pada waktu yang sama.

Kondisi saat sel solar cell dalam kondisi short circuit, arus maksimum atau arus short circuit (Isc) dihasilkan, sedangkan pada kondisi open circuit tidak ada arus yang dapat mengalir sehingga tergangannya maksimum, disebut tegangan open circuit (Voc). Titik pada kurva I-V yang menghasilkan arus dan tegangan maksimum disebut titik daya maksimum pada titik. Daya maksimum ini terjadi saat $\mathrm{I}_{\mathrm{sc}}$ dan $\mathrm{V}$ pada saat maksimum.

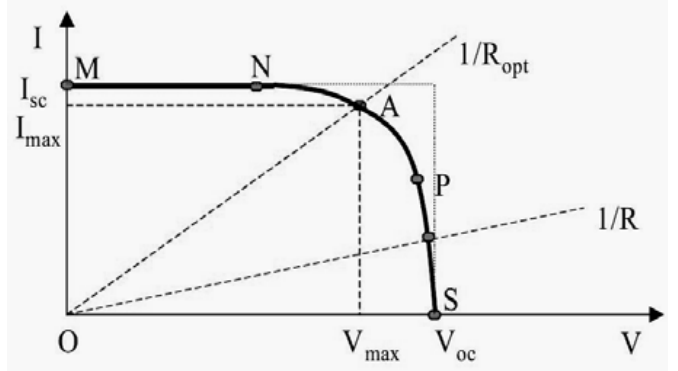

Gambar 2. Karakteristik kurva I-Vsolar cell

Performa solar cell selain intersitas cahaya matahari, kemiringan sudut solar cell juga dipengaruhi oleh temperatur permukaan solar cell, kenaikan temperatur permukaan solar cell dapat menurunkan performa solar cell.

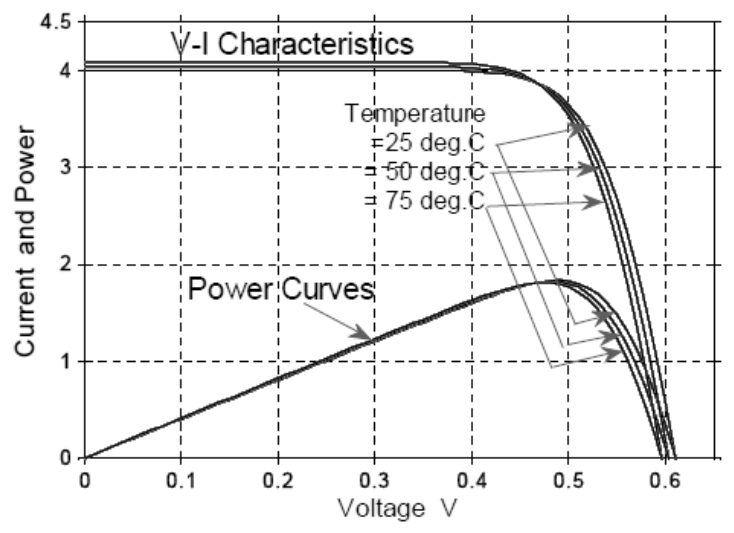

Gambar 3. Kurva karakteristik i-v terhadap perubahan temperatur

Perubahan iradiasi pada permukaan sel solar cell mempengaruhi kinerja solar cell, hal ini terlihat pada penurunan arus listrik dan tegangan solar cell pada saat terjadi penurunan cayaha matahari yang mengenai permukaan sel solar cell.

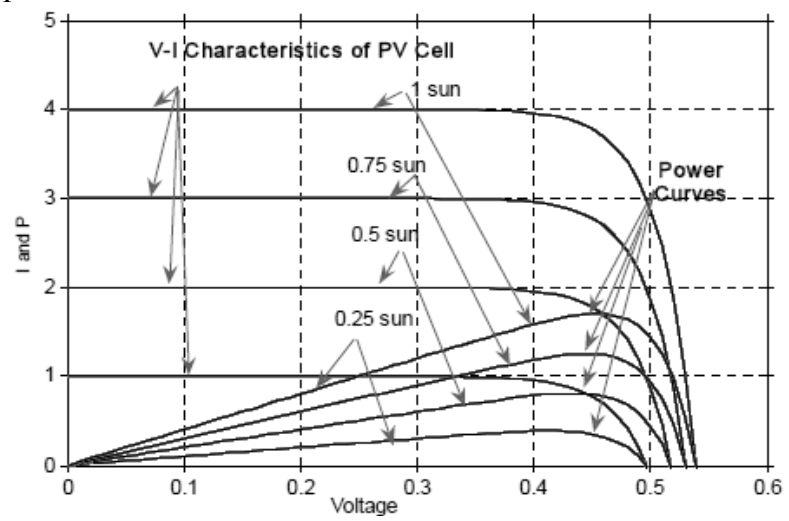

Gambar 4. Kurva karakteristik i-v terhadap perubahan

iradiasi

Skema ekivalen sebuah solar cell menggambarkan karakteristik tegangan-arus keadaan gelap dan keadaan penyinaran

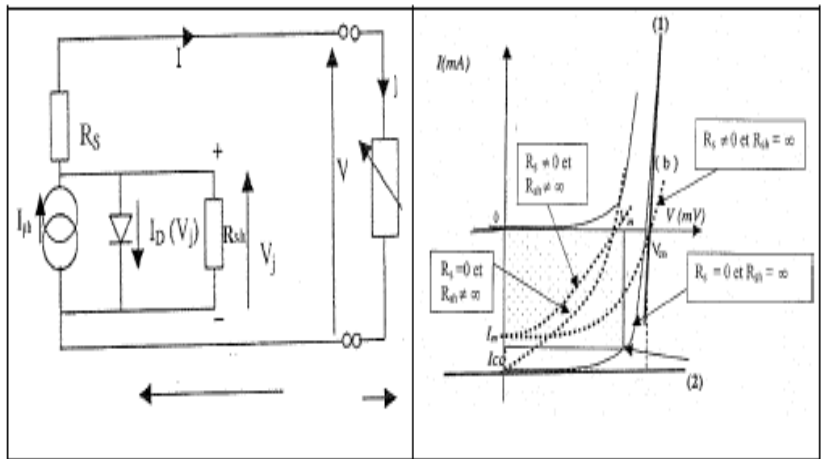

Gambar 5. Karakteristik tegangan-arus keadaan gelap dan penyinaran solar cell 
Karakteristik arus - tegangan (I - V) sambungan P-N dapat diturunkan sebagai berikut;

$$
\mathrm{I}=\mathrm{I}_{\mathrm{ph}}-\mathrm{I}_{\mathrm{d}}-\frac{\mathrm{V}+\mathrm{R}_{s} \mathrm{I}}{\mathrm{R}_{s h}}
$$

Arus diode Id merupakan jumlahan dari arus mayoritas ID dar arus generasi-rekombinasi IR.

$$
\mathrm{I}_{\mathrm{d}}=\mathrm{I}_{D}+\mathrm{I}_{R}=\mathrm{I}_{0} D\left(\exp \frac{\mathrm{qV}_{\mathrm{a}}}{\mathrm{k}_{\mathrm{B}} \mathrm{T}}-1\right)+\mathrm{I}_{\mathrm{OR}}\left(\exp \frac{\mathrm{qV}_{\mathrm{a}}}{2 \mathrm{k}_{\mathrm{B}} \mathrm{T}}-1\right)
$$

Va adalah tegangan terpasang, kB konstanta Boltzmann, dan $\mathrm{T}$ adalah suhu mutlak dalam Kelvin, dengan demikian persamaan arus listrik adalah sebagai berikut;

$$
I=I_{p h}-I_{0}\left[\exp \left(\frac{q V+R_{s} I}{n^{B} T}\right)-1\right]-\frac{V+R_{s} I}{R_{s h}}
$$

I0 adalah arus jenuh diode.

Untuk menyederhanakan perhitungan parameter solar cell ideal, tahanan seri Rs diambil nol dan tahanan paralel Rsh adalah tak berhingga, sehingga diperoleh persamaan karakteristik I-V:

$$
\mathrm{I}=\mathrm{I}_{\mathrm{ph}}-\mathrm{I}_{0}\left[\exp \left(\frac{\mathrm{qV}}{\mathrm{nk}_{\mathrm{B}} \mathrm{T}}\right)-1\right]
$$

$\mathrm{n}$ menyatakan ketidakidealan diode $(\mathrm{n}=1$ untuk diode ideal). Untuk rangkaian terbuka $(\mathrm{I}=0)$, maka diperoleh Voc yang besarnya dapat dinyatakan dengan rumus;

$$
\mathrm{V}_{\propto \mathrm{c}}=\mathrm{n}\left(\frac{\mathrm{k}_{\mathrm{B}} \mathrm{T}}{\mathrm{q}}\right) \ln \left(\frac{\mathrm{I}_{\mathrm{ph}}}{\mathrm{I}_{0}}+1\right) \approx \mathrm{n}\left(\frac{\mathrm{k}_{\mathrm{B}} \mathrm{T}}{\mathrm{q}}\right) \ln \left(\frac{\mathrm{I}_{\mathrm{ph}}}{\mathrm{I}_{0}}\right)
$$

Efisiensi konversi $(\eta)$ adalah perbandingan antara daya listrik maksimum dan daya matahari yang datang mengenai permukaan solar cell, dengan factor bentuk FF (fill factor) yang berkaitan dengan keidealan diode memungkinkan dapat dinyatakan efisiensi dengan paramaeter optimal Icc dan Vco. Icc adalah arus ketika rangkaian terhubung pendek $(\mathrm{V}=0)$. Sedangkan tegangan rangkaian terbuka Vco $(\mathrm{I}=0)$ menggambarkan mekanisme rekombinasi dalam solar cell. Faktor bentuk FF dapat dinyatakan dalam persamaan

$\mathrm{FF}=\mathrm{FI}\left(1-\frac{\mathrm{V}_{\mathrm{co}}}{\mathrm{R}_{\mathrm{sh}} \mathrm{I}_{\mathrm{cc}}}-\frac{\mathrm{I}_{\mathrm{cc}} \mathrm{R}_{\mathrm{s}}}{\mathrm{V}_{\mathrm{co}}}-\frac{\mathrm{R}_{5}}{\mathrm{R}_{\mathrm{sh}}}\right)$

Selanjutnya dapat dinyatakan hubungan antara faktor idealitas diode (FI), Vco dan $\mathrm{n}$ dalam bentuk persamaan;

$\mathrm{FI}=\frac{\mathrm{I}_{\mathrm{m}} \mathrm{V}_{\mathrm{m}}}{\mathrm{I}_{\mathrm{cc}} \mathrm{V}_{\mathrm{co}}}=\frac{\mathrm{V}_{\mathrm{m}}\left(\mathrm{I}_{\mathrm{cc}}-\mathrm{I}_{0}\left(\exp \frac{\mathrm{qV}_{\mathrm{m}}}{\mathrm{nkT}}-1\right)\right)}{\mathrm{V}_{\mathrm{co}} \mathrm{I}_{0}\left(\exp \frac{\mathrm{qV}_{\mathrm{co}}}{\mathrm{nkT}}-1\right)}$

Jika zo $=\mathrm{qVco} / \mathrm{nkT}$ dan $\mathrm{zm}=\mathrm{qVm} / \mathrm{nkT}$, FI dapat dinyatakan :

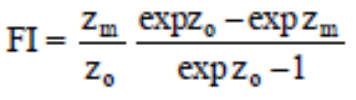

\section{A. Parameter Kinerja Turbin Angin Sumbu Vertikal}

Energi angin merupakan energi terbarukan yang dapat diproduksi kembali melalui proses alam. Kecepatan angin di Indonesia berkisar antara $2 \mathrm{~m} / \mathrm{s}$ hingga $6 \mathrm{~m} / \mathrm{s}$, sedangkan untuk mengkonversi energi angin mengjadi energi listrik dibutuhkan sebuah turbin angin. Turbin angin merupakan devais yang dapat merubah energi angin menjadi energi mekanik untuk menggerakkan generator listrik. Keuntungan menggunakan turbin angin adalah tidak mengeluarkan gas-gas sisa pembakaran seperti karbon monoksida (CO) yang menimbulkan polusi lingkungan. Salah satu model turbin angin yang dapat digunakan adalah turbin sumbu vertikal dengan konstruksi sumbu rotasinya tegak lurus terhadap permukaan tanah. Jika dibandingkan efisiensi turbin, turbin angin sumbu horisontal lebih efektif dalam mengekstrak energi angin dibandingkan turbin angin sumbu vertikal. Tetapi turbin angin sumbu vertikal juga memiliki keunggulan, yaitu; tidak harus diubah posisinya jika arah angin berubah, tidak memerlukan mekanisme tambahan untuk menyesuaikan rotor turbin dengan arah angin, tidak membutuhkan struktur menara yang besar, konstruksi turbin sederhana, dapat didirikan dekat dengan permukaan tanah [5]. Kinerja turbin vertical axis wind (VAWT) skala prototipe untuk mengevaluasi kinerjanya dengan beberapa parameter geometris yang dimodifikasi dengan terowongan angin $40 \mathrm{~cm} \times 40 \mathrm{~cm}$ perubahan sudut pitch sangat berpengaruh pada daya keluaran turbin angin karena berkaitan dengan kinerja aerodinamika rotor turbin angin. Dengan mengatur sudut pitch pada kondisi optimal maka akan didapat daya yang maksimal [6].

Prinsip konversi energi angin yang digunakan untuk menghitung besarnya energi kinetic yang dihasilkan. Energi angin dilihat dari energi kecepatan aliran angin, dapat dituliskan dalam bentuk persamaan energi kinetik $\left(\mathrm{E}_{\mathrm{k}}\right)$.

$$
E_{k}=\frac{1}{2} m u_{0}^{2}
$$

dimana $: \mathrm{m}=$ massa angin yang mengalir $(\mathrm{kg})$

$$
\mathrm{u}_{0}=\text { kecepatan angin }(\mathrm{m} / \mathrm{s})
$$

Energi kinetik angin inilah yang diekstrak sudu turbin angin untuk diubah menjadi energi mekanis. Dilihat dari pemodelan Betz', kecepatan angin $\mathrm{u}_{0}$ dan kerapatan $\rho$ dengan luas sapuan rotor turbin $\mathrm{A}_{1}$, daya angin yang dapat diekstrak turbin angin adalah:

$$
P_{T}=\frac{1}{2} C_{p} A_{1} \rho u_{0}^{3}
$$

Daya Turbin, adalah laju energi yang dapat diserap oleh turbin dari angin yang merupakan hasil perhitungan dari variabel yang diukur seperti beban, ketinggian dan waktu. Adapun persamaannya adalah sebagai berikut

$P_{T}=T . \omega$

dimana: $\quad \mathrm{P}_{\mathrm{T}}=$ daya (watt) 
$\omega=$ Putaran turbin (rps)

$$
\mathrm{T}=\text { Torsi pengereman (N.m) }
$$

Daya Angin, adalah laju potensi energi yang tersedia oleh angin yang besarnya merupakan hasil pengukuran kecepatan angin dan data spesifik dari bilah yang mengikuti persamaan berikut :

$$
P_{A}=0,5 \rho U_{A}^{3} S
$$

dimana: $\rho=$ Massa jenis udara $\left(\mathrm{kg} / \mathrm{m}^{3}\right)$

$$
\begin{gathered}
U_{A}=\text { kecepatan angin }(\mathrm{m} / \mathrm{det}) \\
S=\text { Span Area }\left(\mathrm{m}^{2}\right)
\end{gathered}
$$

Effisiensi turbin $\left(\mathrm{C}_{\mathrm{P}}\right)$ adalah perbandingan daya yang dapat diserap turbin dengan daya angin yang mengikuti persamaan berikut :

$$
C_{P}=\frac{P_{T}}{P_{A}}
$$

Tip speed Ratio $(\lambda)$ adalah perbandingan kecepatan bilah turbin dengan kecepatan angin di formulasikan sebagai berikut :

$$
\lambda=\frac{\omega \cdot R}{U_{A}}
$$

Dimana, $\omega=$ Kecepatan putar turbin (rpm)

$$
\mathrm{R}=\text { Panjang lengan pemegang bilah }(\mathrm{m})
$$

Kerapatan turbin $(\sigma)$ adalah perbandingan luasan bilah turbin dengan luasan sapuan turbin yang di formulasikan sebagai berikut : $\quad \sigma=\frac{N . c}{D}$

$$
\text { (17) }
$$

dimana: $\mathrm{N}=$ Jumlah bilah

$\mathrm{c}=$ Panjang chord $(\mathrm{m})$

$\mathrm{D}=$ Diameter lengan pemegang bilah

\section{Tip Speed Ratio $(\lambda)$}

Tip speed ratio (rasio kecepatan ujung) adalah rasio kecepatan ujung rotor terhadap kecepatan angin bebas. Untuk kecepatan angin nominal yang tertentu, tip speed ratio akan berpengaruh pada kecepatan putar rotor.

$$
\lambda=\frac{\pi D n}{60 v}
$$

\section{Daya Listrik Yang Dapat Dibangkitkan (Pe)}

Daya listrik yang dapat dihasilkan oleh turbin diperoleh melalui persamaan berikut :

$$
P_{e}=\eta_{g} \eta_{T} \frac{1}{2} C_{p, \max } \rho A_{2} v_{1}^{3}
$$

\section{Teknologi Pembangkit Listrik Hybrid Energi Terbarukan}

Integrasi sumber energi angin dan solar cell untuk pembangkit listrik sangat penting untuk mereduksi pencemaran lingkungan yang disebabkan polutan CO [7]. Pembangkit Listrik Tenaga Hibrida (PLTH) dipesisir pantai dengan memadukan beberapa sumber energi baru dan terbarukan, seperti; energi angin dan energi matahari

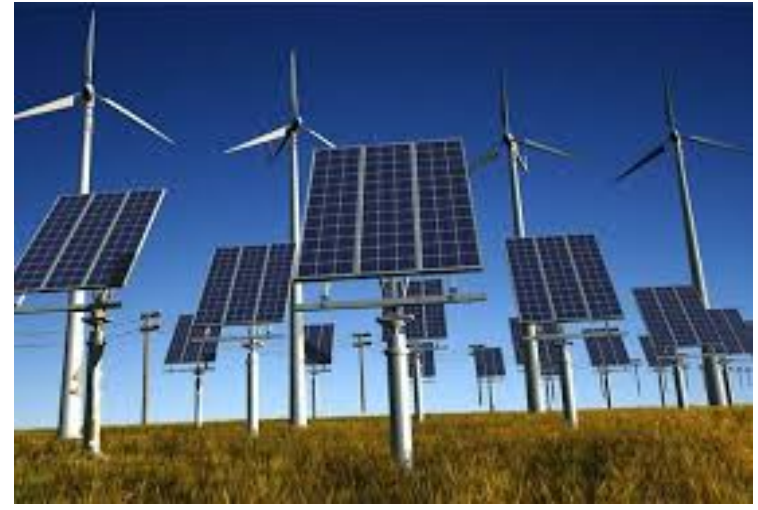

Gambar 6. Model pembangkit listrik hibrid

Pembangkit listrik hibrid dalam sistem pengabungan sumber pembangkit listrik mempunyai model penggabungan sumber pembangkit. Model pembangkit listrik hibrid dengan kombinasi sumber energi yang dapat diperbaharui (renewable) dengan yang tidak dapat diperbaharui (unrenewable), sebagai berikut;

1. Pembangkit-pembangkit dan baterai dipasang disuatu lokasi dan dihubungkan ke AC bus sebelum dikoneksikan ke grid.

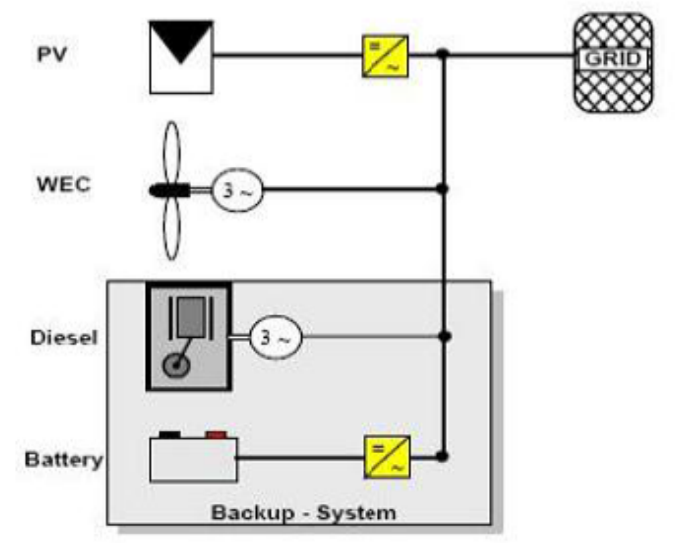

Gambar 7. Model pembangkit listrik hibrid

2. Pembangkit terdistribusi pada lokasi yang berbeda dan setiap pembangkit di koneksikan ke grid secara terpisah. 


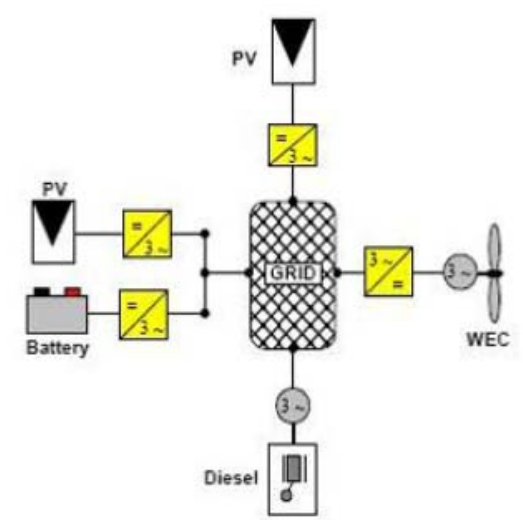

Gambar 8. Konsep arsitektur setiap pembangkit di koneksikan ke grid secara terpisah

3. Dilakukan konversi tegangan AC ke DC pada pembangkit yang menghasilkan daya AC. Selanjutnya daya DC tersebut dikoneksikan ke DC bus dan sebuah pengubah tegangan $\mathrm{DC}$ ke $\mathrm{AC}$ digunakan untuk mengumpankan ke grid (AC).

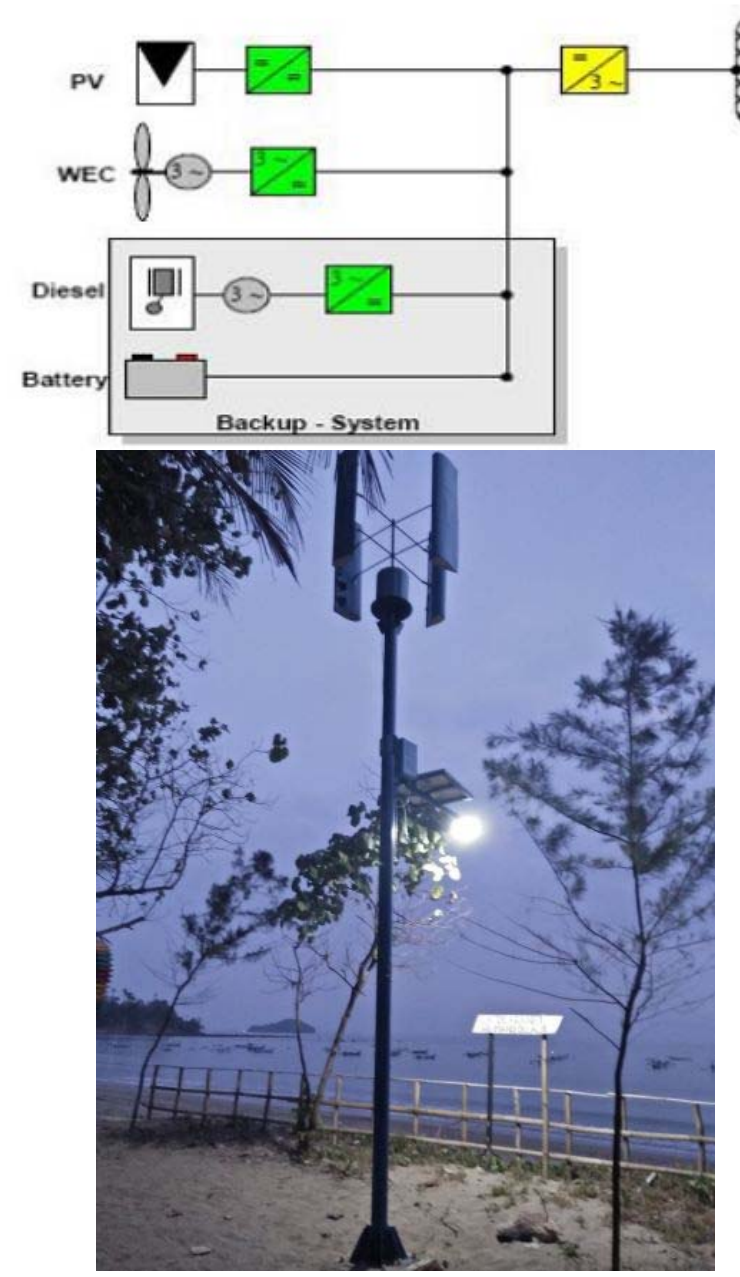

Gambar 9. Konsep arsitektur sebuah pengubah tegangan DC ke AC digunakan untuk mengumpankan ke grid (AC).

\section{Metode Penelitian}

Metode penelitian adalah mendesain model pembangkit listrik hybrid dengan menggunakan turbin angin darrieus- $\mathrm{H}$ NACA 0018 modifikasi dengan jumlah blade 4 buah, dengan sudut pith $10^{\circ}$ dan $20^{\circ}$ untuk menggerakkan generator AC 300 watt 3 fase dan modul solar cell 1000 WP monokristal yang digunakan untuk mengkonversi energi angin dan energi matahari menjadi listrik. Variabel penelitian yang dikontrol adalah dimensi turbin angin vertikal darrieus-H NACA 0018 modifikasi dengan spesifikasi diameter turbin $1000 \mathrm{~mm}$, tinggi turbin 120 $\mathrm{mm}$, lebar blade $300 \mathrm{~mm}$, tinggi blade $1200 \mathrm{~mm}$, tinggi pemasangan turbin $5000 \mathrm{~mm}$. Modul solar cell monokristal $100 \mathrm{Wp}$. Parameter yang diukur adalah daya listrik yang dihasilkan turbin angin dan solar cell dengan mengukur perubahan tegangan dan arus listrik yang dihasilkan. Analisis data menggunakan analisis kuantitatif-deskriptif dengan menampilkan data-data dalam bentuk grafik dan dijabarkan secara deskriptif untuk menarik kesimpulan. Instrumen penelitian pembangkit listrik hibrid dipesisir pantai ditampilkan seperti gambar 10 .

Gambar 10. Pembangkit listrik hibid solar cell dan turbin angin

\section{Pembahasan dan Analisis}

Performa merupakan salah satu parameter untuk mengetahui kinerja sebuah alat bekerja. Performa pembangkit listrik hybrid merupakan hasil dari perbandingan antara daya listrik yang dihasilkan dari masing-masing pembangkit listrik dengan kebutuhan listrik yang dapat suplai dari pembakit tersebut.

Tabel 1. Daya solar cell

\begin{tabular}{|c|c|c|c|c|}
\hline NO & $\begin{array}{c}\text { Wak } \\
\text { tu }\end{array}$ & Daya (W) & $\begin{array}{c}\text { Intensitas } \\
\text { Cahaya } \\
\left(\mathbf{W} / \mathrm{m}^{2)}\right.\end{array}$ & efisiensi \\
\hline 1 & 08.00 & 44,70 & 860 & $7.94 \%$ \\
\hline
\end{tabular}




\begin{tabular}{|c|c|c|c|c|}
2 & 08.15 & 45,66 & 864 & $8.17 \%$ \\
\hline 3 & 08.30 & 50,24 & 882 & $8.70 \%$ \\
\hline 4 & 08.45 & 46,54 & 873 & $8.44 \%$ \\
\hline 5 & 09.00 & 50,65 & 888 & $8.86 \%$ \\
\hline 6 & 09.15 & 52,13 & 895 & $9.35 \%$ \\
\hline 7 & 09.30 & 54,79 & 894 & $9.16 \%$ \\
\hline 8 & 09.45 & 55,66 & 899 & $9.56 \%$ \\
\hline 9 & 10.00 & 56,88 & 922 & $9.82 \%$ \\
\hline 10 & 10.15 & 60,48 & 924 & $10.00 \%$ \\
\hline 11 & 10.30 & 56,88 & 922 & $9.82 \%$ \\
\hline 12 & 10.45 & 60,48 & 924 & $10.00 \%$ \\
\hline 13 & 11.00 & 66,88 & 969 & $10.55 \%$ \\
\hline 14 & 11.15 & 67,97 & 989 & $10.70 \%$ \\
\hline 15 & 11.30 & 69,07 & 995 & $11.01 \%$ \\
\hline 16 & 11.45 & 73,64 & 1015 & $11.13 \%$ \\
\hline 17 & 12.00 & 74,91 & 1024 & $11.33 \%$ \\
\hline 18 & 12.15 & 75,39 & 1036 & $11.37 \%$ \\
\hline
\end{tabular}

\begin{tabular}{|c|c|c|c|c|}
19 & 12.30 & 76,30 & 1045 & $11.56 \%$ \\
\hline 20 & 12.45 & 81,25 & 1058 & $11.98 \%$ \\
\hline 21 & 13.00 & 81,71 & 1060 & $12.08 \%$ \\
\hline 22 & 13.15 & 81,42 & 1057 & $11.97 \%$ \\
\hline 23 & 13.30 & 80,93 & 1054 & $11.83 \%$ \\
\hline 24 & 13.45 & 80,47 & 1052 & $11.74 \%$ \\
\hline 25 & 14.00 & 76,54 & 1049 & $11.60 \%$ \\
\hline 26 & 14.15 & 76,03 & 1043 & $11.44 \%$ \\
\hline 27 & 14.30 & 72,00 & 1012 & $10.87 \%$ \\
\hline 28 & 14.45 & 60,97 & 900 & $10.51 \%$ \\
\hline 29 & 15.00 & 46,90 & 875 & $8.58 \%$ \\
\hline 30 & 15.15 & 26,47 & 725 & $5.73 \%$ \\
\hline 31 & 15.30 & 25,74 & 712 & $5.44 \%$ \\
\hline 32 & 15.45 & 22,65 & 683 & $5.26 \%$ \\
\hline 33 & 16.00 & 21,14 & 667 & $4.88 \%$ \\
\hline & Total & $1,980 \mathrm{KW}$ & & \\
\hline
\end{tabular}

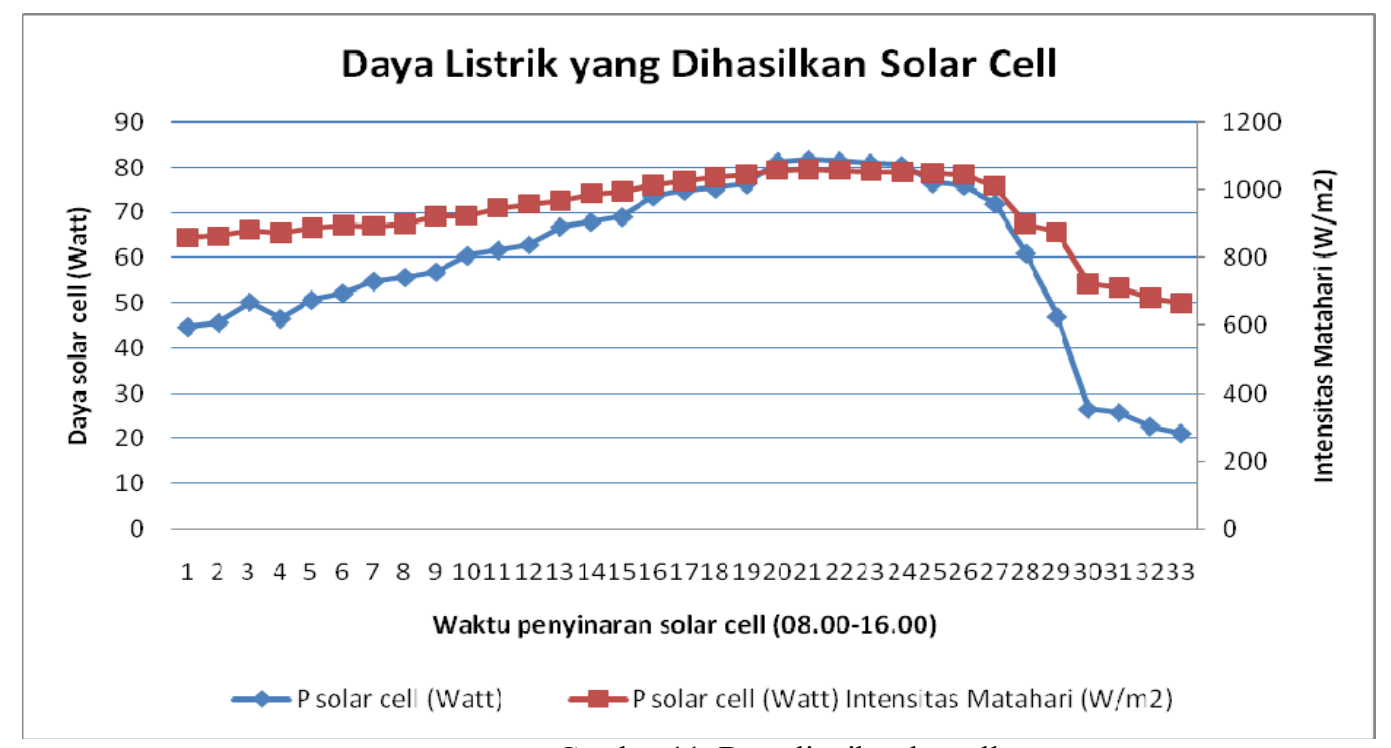

Gambar 11. Daya listrik solar cell

Performa dengan nilai daya dan efisiensi tertinggi (tabel 1) menujukkan pukul 13.00 menghasilkan daya listrik 83,71 watt daya dan efisiensi $12,08 \%$, sedangkan nilai daya dan efisiensi solar cell terendah pada pukul 16.00 sebesar 21,14 watt dan efisiensi 4,88\%. Sedangkan total energi listrik yang dihasilkan solar cell selama satu hari mulai pukul 08.00-16.00 sebesar 1,980 KW. Performa dari beban rencana 25 sampai $100 \mathrm{~W}$ mengalami kenaikan. Hal ini dikarenakan selisih antara Pin dengan Pout berbanding lurus dengan beban rencana. Jika selisih antara Pin dengan Pout semakin kecil, maka performa pembangkit semakin besar. Jadi bisa dibilang daya Pin akan banyak terbuang apabila menggunakan beban rencana yang kecil namun daya Pin akan efisien digunakan dengan beban rencana yang besar.

Sedangkan untuk mendukung kerja dari solar cell digunakan pembangkit listrik turbin angin sebagai sumber energi skunder pada sistem pembangkit listrik hybrid. Penggunaan turbin angin vertikal model darrieus-H NACA $0018 \mathrm{~m}$ modifikasi dengan 4 blade dengan sudut pitch $10^{0}$ dan $20^{\circ}$ menunjukkan Performa seperti terlihat pada gambar 12, pada sudut pitch $10^{0}$ menghasilkan energi listrik maksimal yang dihasilkan 33,22 watt pada kecepatan angin $5,5 \mathrm{~m} / \mathrm{s}$, sedangkan energi listrik sudut pitch $20^{\circ}$ menghasilkan energi listrik 32,56 watt pada kecepatan angin $5,6 \mathrm{~m} / \mathrm{s}$. Kecepatan angin semakin tinggi menyebabkan penurun kinerja turbin angin, hal ini diduga 
semakin tinggi kecepatan angin maka putaran turbin juga semakin tinggi sehingga turbin angin seakan-akan menjadi silinder yang menghambat sebagian udara untuk masuk kesisi dalam dari turbin angin sehingga laju aliran massa udara yang berguna untuk menggerakkan turbin angin berkurang yang pada akhirnya daya yang dapat ekstrak oleh turbin angin juga berkurang.
Energi listrik yang dihasilkan genertor turbin mengalami peningkatan, hal ini disebabkan daya yang dihasilkan turbin dan koefisien kinerja turbin sudut pitch hingga sudut $10^{\circ}-20^{\circ}$, hal disebabkan pada sudut ini nilai koefisien lift dari bilah profile NACA 0018 modifikasi bertambah besar namun jika sudut pitch diperbesar lagi maka akan timbul fenomena dynamic stall (Ragheb, 2013) karena aliran terseparasi di ujung bilah.

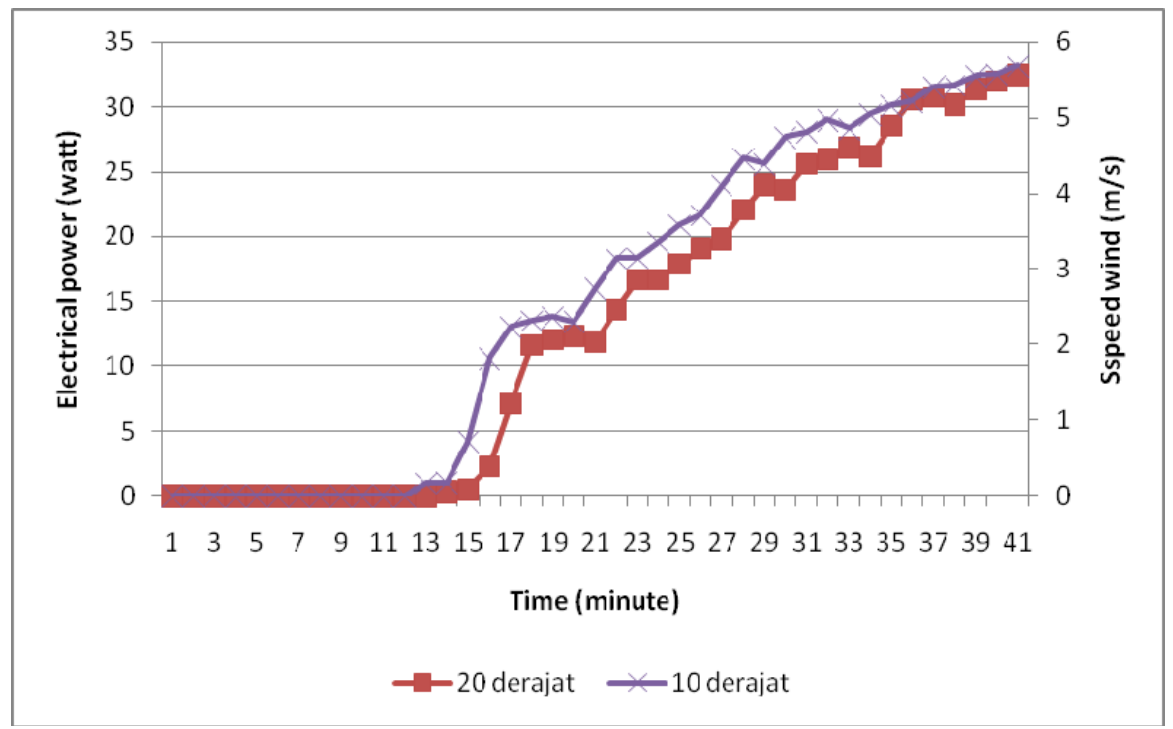

Gambar 12. Daya listrik turbin angin darrieus NACA airfoil 4 blade dengan sudut pitch $10^{\circ}$ dan $20^{\circ}$

Suplai kebutuhan energi listrik dari model pembangkit listrik hybrid soalt cell-turbin angin dipesisir pantai menunjukkan tingkat kelayakan dengan kondisi sumber energi matahari dengan intensitas rata-rata 600 $1060 \mathrm{~W} / \mathrm{m}^{2}$ yang dapat dikonversi dengan modul solar cell $100 \mathrm{WP}$ menghasilkan daya listrik rata-rata 1,98 KW/hari. sedangkan potensi angin dengan kecepatan rata-rata 2- 6 $\mathrm{m} / \mathrm{s}$ dapat menghasilkan energi listrik rata-rata 33,2-33,5 watt. Performa pembangkit listrik tenaga hybrid mengalami peningkatan seiring dengan bertambahnya daya beban rencana. Performa tertinggi terdapat pada beban 100 W dengan efisiensi sebesar 64,72\%. Sedangkan efisiensi terendah terdapat pada beban $25 \mathrm{~W}$ dengan efisiensi sebesar $63,68 \%$.

\section{KESIMPULAN}

Model pembangkit listrik solar cell-turbin angin dapat mengahsilkan daya listrik solar cell 1,98 KW per hari dan pembangkit listrik turbin angin rata-rata menghasilkan 33,2-33,5 watt, model pembangkit listrik hybrid solar cellturbin angin dipesisr pantai dapat dimanfaatkan sebagai sumber pembangkit listrik dengan menggunakan model sistem solar cell sebagai sumber pembangkit utama atau primer dan turbin angin sebagai sumber pembangkit skunder pada sistem hybrid. Model hybrid dapat digunakan untuk memenuhi kebutuhan energi listrik di daerah pesisir pantai tamban. Performa pembangkit listrik tenaga hybrid mengalami peningkatan seiring dengan bertambahnya daya beban rencana. Performa tertinggi terdapat pada beban 100 W dengan efisiensi sebesar $64,72 \%$. Sedangkan efisiensi terendah terdapat pada beban $25 \mathrm{~W}$ dengan efisiensi sebesar $63,68 \%$. Konsumsi energi listrik rata-rata untuk penerangan sebesar $1 \mathrm{KWh} /$ hari setiap KK dengan aplikasi pembangkit listrik hybrid solar cell-turbin angin masih kelebihan energi, sehingga model pembangkit listrik hybrid solar cellturbin angin memiliki efektifitas dan efisien yang baik untuk diterapkan di daerah pesisir pantai.

\section{Ucapan Terima Kasih}

Ucapan terima kasih kepada Kementrian Riset, Teknologi dan Pendidikan Tinggi, yang telah membantu dalam pendanaan penelitian pada skim Penelitian Insinas Riset Pratama Individu dengan no kontrak No. 0018/UN38.11P/LT/2017.

\section{Referensi}

[1] Al-Hasan A. Electricity generation cost between proposed photovoltaic station and conventional units in Kuwait. Renewable Energy 1997;12(3):291-301.

[2] SEIA. 2014. Solar energy technologies solutions for today's energy need [Online], Retrieved March 13, 2017 from the 

http://www.seia.org/sites/default/files/SolarEnergy TechnologiesOverview11-13-2014.pdf.

[3] Knier G. 2008. How do photovoltaics work [Online], Retrieved March 13, 2017 from the World Wide Web: $\mathrm{http}: / /$ science.nasa.gov/science- news/science-atnasa/2002/solarcells.

[4] Al Dousari A, Ahmed M, Al Dousari N, Al Awadhi S. Environmental and economic importance of native plants and green belts in controlling mobile sand and dust hazards. Int J Env Sci Tech, 2018;

[5] Nugroho, P. E., (2011), Rancang Bangun Turbin Angin Sumbu Vertikal Mikro Wind Energy Skala Rumah Tangga. Teknik Mesin, UMS. Surakarta.

[6] Villara, F. G., Jimeneza, E. T., Vicentea, R. D., \& Gonzáleza, J.I. J. (2015). Development of Vertical Wind Turbines via FDM Prototype. Journal of Procedia Engineering, 132, 78 85

[7] Mehdi Jahangiria, Ahmad Haghania, Ali Mostafaei pourb, Adel Khosravic, Heidar Ali Raeisic. AssessmentofsolarwindpowerplantsinAfghanistan:Areview

RenewableandSustainableEnergyReviews 99.(2019) 169190. 